\title{
The Relationship of Interpersonal Communication, Organizational Commitment and Supervision to Principal's Performance
}

\author{
${ }^{1}$ Wawan Ridwan, ${ }^{2}$ Soewarto Hardhienata, ${ }^{3}$ M. Entang \\ ${ }^{1,2,3}$ Post Graduate Program, Universitas Pakuan Bogor, Indonesia
}

\begin{abstract}
The aim of this study is to examine the influence of interpersonal communication, organizational commitment and supervision to principal's performance either individually or jointly. Variables of interpersonal communication, organizational commitment and supervision function as independent variables while the dependent variable is principal's performance. The research was conducted on proportional randomly selected 162 principals of public elementary school in Cianjur region, West Java, Indonesia. Using mix method, sequential explanatory design is applied where quantitative come first. The study both quantitatively and qualitatively reveals that there is a positive significant relationship among variables under the following distribution of coefficient of correlation: interpersonal communication to principal's performance $=0.552$, organizational commitment to principal's performance $=0.468$, supervision to principal's performance $=0.454$ and when tested together it produces coefficient of determination $=0.424$ indicating the existence of other 57.6 $\%$ variables not including in the model affecting principal's performance within the public elementary school principals'working environment.
\end{abstract}

Keywords: Interpersonal Communication, Organizational Commitment, Supervision, Principals' performance

\section{INTRODUCTION}

The performance of school principals is a significant factor in the process of achieving the educational goals of the school implying that if the performance of the school principal is good then school progress will be achieved and vice versa. As educational leaders, the principals are required to work hard to manage all activities in the school as effectively and efficiently as possible so that the educational process at school runs as expected. Furthermore, performance is one of the principal dominant factors in improving the quality of school education as the key task of the principal is managing and organizing educational services for all students in the school to achieve quality education.

In addition to the principal managerial capabilities and organizational commitment that grow in it, the performance of principals is also determined by the role of the supervisor of the principals in conducting supervision at the unit level of education both in academic and managerial supervision.

Supervision of the principal is in an effort to improve and enhance the performance of the principals in carrying out the functions/roles in order to achieve maximum results. Form of coaching by supervisors to principals, among others by setting the strategic directions through the formulation, implementation, and evaluation which allows schools to achieve goals effectively and efficiently.

Currently, in Cianjur regency there are 1233 public elementary schools plus 14 private elementary schools. The number of public primary schools are spread over 32 districts in Cianjur. Thus, there are as many as 1233 head of the public primary schools and 14 private elementary school principals whose responsibilities are to manage and develop education in each educational unit.

Based on data obtained from the District Education Office in Cianjur, the quality of educational services in Cianjur is still fairly good. A number of obstacles and barriers to the performance of principals are often found thus impacting the quality of education in schools.

The above description shows that the high performance of the principals are of paramount importance to ensure the quality of the school. Therefore, the study titled "The Relationship of Interpersonal Communication, Organizational Commitment and Supervision to Principal's Performance" at the public elementary school in Cianjur, West Java, Indonesia needs to be done. 
Based on the background and the results of the identification of the problem, the formulation of the problem is:

1. Does interpersonal communication positively affect public lementary school principal's performance?

2. Does organizational commitment positively affect public lementary school principal's performance?

3. Does supervision positively affect public lementary school principal's performance?

4. Do interpersonal communication, organizational commitment and supervision altogether positively affect public lementary school principal's performance?

\section{LiterATURE REVIEW}

Performance is the level of achievement or the implementation of certain tasks in order to achieve the goals and objectives of education. To know the development of education is to see the results of performance assessment which includes the skill, ability, quality, punctuality, discipline, internal communications activities and communications networks used by members of a particular party (Holtom \&Mitchell, 2008). Performance can also be an individual contribution and systems to achieve organizational goals. Thus, the performance can be said as a whole number and quality of the work produced or services provided by a particular work unit. If produced by an individual, then it is called as the performance of the individual, whereas if it is produced by an organization, it is referred to as the organizational performance. The performance assessment is a process of determining the individual's performance in the past or today compared with the background of the work environment as well as on the future potential for the organization (Castetter, 2004). Performance is the result or performance means the act of displaying or carrying out an activity which is linked by a variety of situations that take place internally and externally individuals. Performance is a result or action displaying or conducting an individual activity that is linked by a variety of situations that take place internally and externally. Performance is the result or the overall success rate of a person during a certain period in carrying out the task compared with a range of possibilities, such as the standard of the work, the target or criteria that have been determined in advance and agreed together with the following indicators: quality of work, promptness, initiative, capability, and communication.

Interpersonal communication is defined as the process of delivering the news carried by a person and the receiving of the news by another person or a small group of people with a good result and immediate feedback with the following the indicator: a) transparency, b) empathy, c) support, d) positivity, e) similarity (Gibson et.al, 2012). Interpersonal communication is the primary mode of communication in managerial days, usually more than a quarter of managerial communication occurs face to face. The indicators are: a) transparency, b) honesty, c) feedback (Robbins, 2012). Interpersonal communication in the organization of the school is an important thing to do among people in schools to improve the relationship between the personal and the smooth process of communication, so that the work in the school organization can run smoothly as expected, in the absence of conflict and obstacles. Taylor et.al (2007) said that effective interpersonal communication includes many elements, but the interpersonal relationships is perhaps the most important. The message should be clear, concise, and accurate.

Organizational commitment is someone's attachment to organization indicated by (1) acceptance of the objectives of the organization; (2) willingness to work hard for the organization; and (3) desire to remain in the organization (Spector, 2008). Organizational commitment is an attitude in form of affective commitment in which emotionally engaged workers identify themselves within organization reflected in prioritizing: (a). justice and support, (b). shared values, (c). trust, (d). organizational comprehension, and (e). employee involvement. (Mc. Shane \& Glinow, 2012). Commitment to the organization has a deeper meaning than just a formal membership as it covers the attitude of liking the organization and willingness to seek a high level of effort for the organization for the achievement of objectives. Based on this definition, the organizational commitment includes elements of loyalty to the organization, involvement in work, and identification with the values and goals of the organization.

Supervision can be defined as the oversight of the work of others by the supervisory authorities to monitor the performance directly and ensure satisfactory performance (Caspi \& Reid, 2002). 
Supervision is the process whereby a supervisor has an understanding of the system used to provide direction for the development of the work (Hawkins, 2013). Supervision is the process of overseeing the ability of people to meet the objectives of the organization in which they work. He stressed that monitoring should be seen as a process, not as a professional role. Supervision, furthermore is defined as activities of supervisor (official designation) done for the improvement of teaching and learning process. Mantja (2016) considers supervision as activities for improvement (student \& teacher) and improving the quality of education.

\section{Data Collection}

This study applies mix method with direct observation to the field aimed at analyzing the phenomenon occur when the research took place then confirm the finding by using direct depth interview. This way, writers apply Sequential Explanatory Mixed Methods. Descriptive statistics and quantitative analysis are used for finding initial solution to the problem encountered. The sample of this study were 162 principals of public elementary school of out of 1233 schools in Cianjur regency, West Java Indonesia after calculated with Slovin's formula. Quantitative methods serve to obtain measurable quantitative data, in this research is associative, and qualitative methods serve to prove, deepen, broaden, give meaning to quantitative data which have been obtained at an early stage.

Techniques of data collection in this study is in the form of questionnaire. The normality assumption is prerequisites to proceed to further test. Analysis is conducted with multiple linear regression and hypothesis testing is performed at a significance level of 0.05 .

\section{RESULT AND DISCUSSION}

The principals of selected schools were asked to participate in the survey by stating their opinions for four different measures on interpersonal communication, organizational commitment and supervision to principal's performance. The normality is performed with Lilliefors test. Data are normally distributed as the value of each variable is not exceeding the critical value for Lilliefors test. The Lilliefors normality test values for interpersonal communication,working motivation, transformational leadership to job satisfaction are $0.064,0.662$ and 0.092 respectively below the critical value of 0.133 for $\mathrm{n}=162$.

\subsection{The Effect of Interpersonal Communication to Principal's Performance}

Hypothesis testing confirms that interpersonal communication positively affects principal's performance with correlation coefficient value of 0.552 and the coefficient of determination $=0.304$. This means that only $30.4 \%$ of principal's performance is determined by interpersonal communication, while the other $69.6 \%$ is contributed by other variables. Similarly, result of qualitative research interviews, focus group discussion, observation and documentation in public elementary school in the region of Cianjur, confirms the tendency of the relationship between interpersonal communication with principal's performance. This finding strengthens the quantitative research hypothesis results testing that there is a positive significant relationship between interpersonal communication and principal's performance.

\subsection{The Effect of Organizational Commitment to Principal's Performance}

Hypothesis testing confirms that organizational commitment positively affects performance with correlation coefficient value of 0.468 and the coefficient of determination $=0.219$. This means that only $21.9 \%$ of principal's performance is determined by organizational commitment, while the other $78.1 \%$ is contributed by other variables. Similarly, result of qualitative research interviews, focus group discussion, observation and documentation in public elementary school in the region of Cianjur, confirms the tendency of the relationship between organizational commitment with principal's performance. This finding strengthens the quantitative research hypothesis results testing that there is a positive significant relationship between organizational commitment and principal's performance.

\subsection{The Effect of Supervision to Principal's Performance}

Hypothesis testing confirms that supervision positively affects performance with correlation coefficient value of 0.454 and the coefficient of determination $=0.206$. This means that only $20.6 \%$ of principal's performance is determined by supervision, while the other $79.4 \%$ is contributed by other variables. Similarly, result of qualitative research interviews, focus group discussion, observ- 
ation and documentation in public elementary school in the region of Cianjur, confirms the tendency of the relationship between supervision with principal's performance. This finding strengthens the quantitative research hypothesis results testing that there is a positive significant relationship between supervision and principal's performance.

\subsection{Interaction of Interpersonal Communication, Organizational Commitment and Supervision to Principals' Performance}

When tested together, hypothesis testing results show that there is a significant relationship between interpersonal communication, organizational commitment and supervision to principals' performance with the coefficient of determination $=0.424$. This means that $42.4 \%$ of principal's performance is determined by variables of interpersonal communication, organizational commitment and supervision while $57.6 \%$ is contributed by other variables not included in the model. Result of qualitative research interviews, observation and documentation in elementary schools in the regency of Cianjur, West Java, Indonesia confirms the relationship the tree mentioned variables to principal's performance. This finding strengthens the quantitative research hypothesis results testing that there is a positive significant relationship among those mentioned variables.

\section{Conclusion}

The findings reveal that there is a positive and significant direct effect between the interpersonal communication, organizational commitment and supervision to principal's performance.

Based on the initial design of the constellation between variables, the results showed that the contribution of interpersonal communication to principal's performance is $30.4 \%$, organizational commitment is $20.6 \%$, and supervision is $21.9 \%$ indicating the highest individual contribution to the principal's performance is interpersonal communication. When combined together, contribution of the three variables reaches $42.4 \%$ indicating the contribution of other variables not included in the model to predict performance are $58.6 \%$ indicating this model is of marginal -fit. Other researchers wishing to conduct similar studies may include other variables such as; principal's professionalism, achievement motivation, work culture of principal, resilience, creativity, work experience, training, principal's management, decision-making techniques and so forth.

\section{REFERENCES}

Castetter, William B. The Human Resources Function in Educational Administration, 2004, New Jersey: Pearson/Merrill/Prentice Hall. pp. $314-315$.

Caspi, J., \& Reid, W. J. (2002). Educational supervision in social work: A task-centred model for field instruction and staff development. New York, NY: Columbia University Press.

Gibson, J.L., John M. Ivancevich, James H. Donelly Jr, \& Robert Konopaske. Organizational: Behavior, Structure, Processes, 2012, New York: Mc Graw-Hill. pp. 344-345.

Holtom, B. C., Mitchell, T. R., Lee, T. W., \& Eberly, M. B. (2008). 5 turnover and retention research: a glance at the past, a closer review of the present, and a venture into the future. The Academy of Management Annals, 2(1), 231-274.

Hawkins, P., 2013. Coaching, mentoring and organizational consultancy: Supervision, skills and development. McGraw-Hill Education (UK).

Mantja, W., 2016. Manajemen Pendidikan dalam Era Reformasi. Jurnal Ilmu Pendidikan, 7(2).

McShane/Von Glinow, Organizational Behavior, Emerging Knowledge and Practice for the Real World, 2010, pp. 202. New York: McGraw-Hill Irwin.

Robbins, S. P. \& T. A. Judge (2012). Organizational Behavior. New Jersey: Pearson Education.

Taylor, A., Bailey, A., Cooper, P., Dwyer, C., Kramarae, C. and Lieb, B., 2007. Gender equity in communication skill. Handbook for achieving gender equity through education, p.281. 